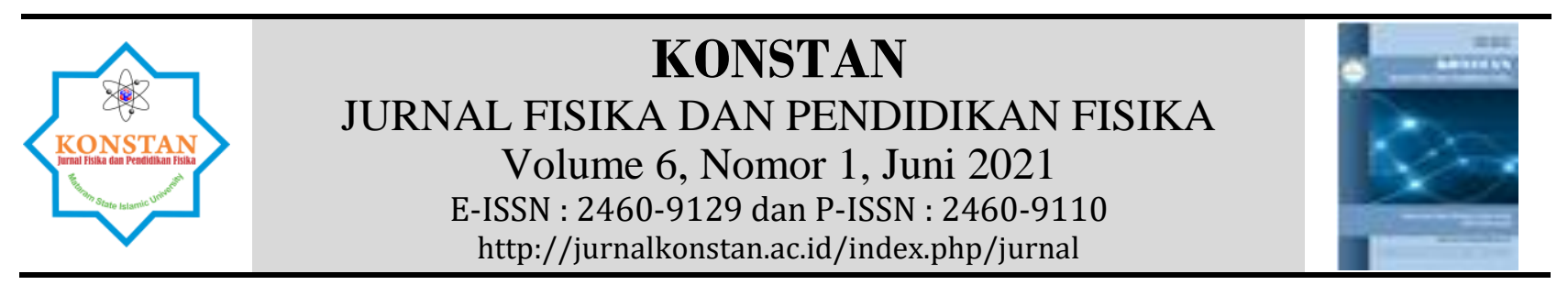

\title{
Karakteristik Sifat Mekanik Wadah Makanan Dari Limbah Daun Pisang Kering
}

\author{
Zilmi Azyurah Rahman ${ }^{1}$, Hernawati ${ }^{1}$, Ayusari Wahyuni ${ }^{1 *}$ \\ 1) Fisika, Fakultas Sains dan Teknologi, UIN Alauddin Makassar, Jl.H.M. Yasin Limpo, Gowa, Sulawesi \\ Selatan, Indonesia \\ *E-mail korespondensi: Ayusari_wahyuni@uin-alauddin.ac.id
}

\begin{abstract}
Info Artikel: Abstract
Dikirim:

20 Januari 2021

Revisi:

11 Juni 2021

Diterima:

14 Juni 2021

Kata Kunci:

The objective of this research is to determine the physical quality of food media, consisting of small plate, large plate and small bowl. The method used of this research is testing the water absorption and resistance of the food media's temperature. The process of making a food media using a stainless steel mold which is heated using a food thermometer with $100^{\circ} \mathrm{C}$ and a load of $10 \mathrm{~kg}$ as a pressure, then it is printed for 5 minutes with 4 times taking the data for each food media. There are two testing of food media, the first test is water absorption with $29.5^{\circ} \mathrm{C}$ for

Daun pisang, Wadah, Bentuk. 125 miles into a small plate, 200 miles into a small bowl and 250 miles into a large plate for 60 minutes, the average value of the water absorption test for the Nonwoven food media consists of three forms food medias have $0.00 \%$ as the same result, meanwhile woven media such as small plate has $0,106 \%$, large plate has $0,005 \%$ and small bowl has $0,005 \%$. Second test is resistance of the food medias based on temperature parameters. The temperatures used were 40, 60, 80 for nonwoven food media consists of three forms food media which had few change after drying, while for woven food media consists three forms of food media had the same results, that is seepage (leaking) in the food media.
\end{abstract}

(C) 2021 Universitas Islam Negeri Mataram

\section{PENDAHULUAN}

Indonesia merupakan negara yang mempunyai keanekaragaman flora yang beragam, berbagai macam tanaman terdapat di Indonesia. Salah satunya yang paling banyak adalah tanaman pisang. Pisang merupakan tanaman dengan harga yang relatif murah dan mudah dibudidayakan. Tanaman ini popular sebagai tanaman serbaguna. Secara umum buahnya memiliki rasa manis sehingga buah pisang merupakan bagian yang sering dikonsumsi oleh masyarakat Indonesia [1]. Sejak zaman nenek moyang tanaman ini digunakan sebagai lauk pendamping dalam setiap sajian. Seperti contohnya jantung pisang, buah pisang dan daun pisang. Daun pisang sangat popular digunakan sebagai pembungkus makanan atau alas untuk hidangan, namun hanya daun pisang yang masih hijau dan segar saja yang banyak digunakan oleh masyarakat sedangkan daun pisang yang sudah kering kurang diperhatikan lagi keberadaannya biasanya daun pisang tersebut hanya dikumpulkan untuk dibakar agar tidak menimbulkan penumpukan sampah. Daun pisang kering atau klaras merupakan salah satu bagian dari pohon pisang yang jarang diperhatikan keberadaannya dan mempunyai kandungan nutrisi cukup tinggi. Pemanfaatan klaras dapat mengurangi limbah pertanian [2]. Daun pisang yang sudah kering memiliki beberapa kandungan nutrisi yang cukup tinggi. Berdasarkan penelitian Suparti 
dan [3], daun pisang kering memiliki kandungan selulosa 10,85\%, lignin 18,21\% dan hemiselulosa $19,95 \%$.

Tanpa disadari semua orang menginginkan hal yang serba praktis untuk dijadikan wadah makanan yang sekali pakai yang langsung dibuang tanpa mengetahui bahaya pada kemasan seperti styrofoam, plastik dan kertas sebagai pembungkus makanan. Wadah makanan seperti Styrofoam dan plastik hanya digunakan sekali dan merupakan bahan yang tidak ramah lingkungan karena sulit terurai.

Dalam kehidupan sehari-hari sering dijumpai wadah makanan sekali pakai seperti stytrofoam tersusun dari polimer- polimer yang berasal dari zat adaptif. Zat-zat aditif dari wadah ini dapat bermigrasi ke makanan yang dikemas, yang berbahaya bagi manusia bersifat karsinogenik [4]. Plastik adalah bahan yang digunakan untuk mewadahi dan membungkus pangan [5], dan Kertas minyak umumnya digunakan untuk membungkus makanan mulai dari gorengan sampai nasi remes, telah lama menggantikan daun pisang [6], Padahal di zaman dahulu nenek moyang kita menggunakan bahan-bahan alami untuk menyajikan makanan. Pada penelitian ini akan dibuat sebuah wadah makanan sekali pakai yang cepat terurai oleh alam mengunakan daun pisang kering untuk pengganti Styrofoam.

Salah satu cara menentukan kualitas fisis pada daun pisang kering dengan cara menentukan porositas yang dinyatakan dalam (\%) yang menghubungkan antara volume benda keseluruhan dan juga berhubungan langsung dengan kerapatan [7] dan Ketahanan wadah terhadap suhu merupakan kemampuan untuk mempertahankan keadaaannya atau kemampuan suatu benda untuk tetap dapat berfungsi dengan baik, kemampuan ini menunjukkan seberapa kuat bahan kemasan atau wadah untuk menyerap hentakan atau daya luar [8], [9].

\section{METODE PENELITIAN}

Penelitian ini dilakukan secara manual menggunakan stainless dengan beban dari bahan beton. Alat dan bahan yang digunakan dalam penelitian ini adalah stainless (piring kecil, mangkok kecil dan piring besar), beban dari beton, gunting, kuas, setrika, panci, sendok, neraca digital, thermometer, air, daun pisang kering, tissue, getah nangka dan air.

Penelitian ini menggunakan dua metode yaitu pengujian porositas wadah makanan terhadap air pada wadah makanan dan pengujian ketahanan wadah terhadap suhu pada wadah makanan [10]. Pengambilan data untuk pengujian porositas wadah makanan terhadap air pada wadah makanan yaitu pada proses pengujian ini terlebih dahulu menyiapkan sampel lalu ditimbang, setelah itu menuangkan air ke wadah tunggu sampai 60 menit lalu membuang air pada wadah dan menimbang kembali untuk melihat pertambahan massa setelah di berikan perlakuan [11], [12]. Sedangkan untuk pengujian ketahanan wadah terhadap suhu pada wadah makanan yaitu pada proses pengujian ini terlebih dahulu menyiapkan sampel, lalu menyiapkan air dengan suhu $80^{\circ} \mathrm{C}, 60^{\circ} \mathrm{C}$ dan $40^{\circ} \mathrm{C}$, setelah itu menuangkan air ke wadah lalu mengamati sampai 30 menit dan membuang air lalu mengamati perubahan terhadap wadah setelah diberikan perlakuan.

\section{HASIL DAN PEMBAHASAN}

\section{A. Hasil Penelitian}

Adapun tahap pengujian wadah makanan pada penelitian ini adalah uji porositas wadah terhadap air dan ketahanan wadah terhadap suhu.

\section{Porositas Wadah Makanan Terhadap Air}

Pengujian porositas wadah terhadap air dilakukan dengan menimbang massa awal kemudian diberi air yang bersuhu normal diberikan volume air sebanyak $125 \mathrm{ml}$ ke wadah piring kecil, $200 \mathrm{ml}$ ke wadah mangkok dan $150 \mathrm{ml}$ ke wadah piring besar selama 60 menit. Pada Tabel 1 terdapat nilai dari hasil uji porositas wadah makanan terhadap air untuk wadah makanan tidak dianyam. 
Tabel 1. Uji Porositas Wadah Makanan Terhadap Air untuk Wadah Tidak Dianyam

\begin{tabular}{|c|c|c|c|c|c|}
\hline \multirow[b]{2}{*}{ No } & \multirow[b]{2}{*}{ Bentuk Wadah } & \multirow{2}{*}{$\begin{array}{c}\text { No } \\
\text { Wadah }\end{array}$} & \multicolumn{2}{|c|}{ Massa } & \multirow{2}{*}{$\begin{array}{c}\text { Hasil } \\
\text { DSA }(\%)\end{array}$} \\
\hline & & & Awal & Akhir & \\
\hline \multirow{3}{*}{1.} & \multirow{3}{*}{ Piring Kecil } & 1 & 5.6 gram & 5.6 gram & 0 \\
\hline & & 2 & 5.6 gram & 5.6 gram & 0 \\
\hline & & 3 & 5.6 gram & 5.6 gram & 0 \\
\hline \multirow{5}{*}{2.} & \multirow[t]{2}{*}{ Rata- rata } & & 5.6 gram & 5.6 gram & 0 \\
\hline & & 1 & 17. 01 gram & 17. 01 gram & 0 \\
\hline & \multirow[t]{2}{*}{ Piring Besar } & 2 & 17. $01 \mathrm{gram}$ & 17.01 gram & 0 \\
\hline & & 3 & $17.01 \mathrm{gram}$ & 17.01 gram & 0 \\
\hline & \multirow[t]{2}{*}{ Rata- rata } & & 17.01 gram & 17.01 gram & 0 \\
\hline 2. & & 1 & 11.34 gram & 11.34 gram & 0 \\
\hline \multirow[t]{3}{*}{3} & \multirow[t]{2}{*}{ Mangkok Kecil } & 2 & 11.34 gram & 11.34 gram & 0 \\
\hline & & 3 & $11.34 \mathrm{gram}$ & 11.34 gram & 0 \\
\hline & Rata- rata & & 11.34 gram & 11.34 gram & 0 \\
\hline
\end{tabular}

Berdasarkan Tabel 1 diperoleh data Uji Porositas Wadah Makanan Terhadap Air wadah makanan dengan berbagai jenis bentuk wadah makanan Seperti Piring besar, Mangkok Kecil dan Piring Kecil. Pertama, wadah makanan dengan bentuk wadah makanan piring kecil ketika diberikan perlakuan volume air sebesar 125 mill selama 60 menit tidak mengalami perubahan dan pertambahan massa memiliki nilai rata-rata adalah $0 \%$. Kedua, wadah makanan dengan bentuk wadah makanan Piring besar ketika diberikan perlakuan volume air sebesar 250 mill selama 60 menit tidak mengalami perubahan dan pertamabahan massa memiliki nilai rata-rata wadah adalah $0 \%$ dan Ketiga, wadah makanan dengan bentuk wadah makanan mangkok kecil ketika diberikan perlakuan volume air sebesar 200 mill selama 60 menit tidak mengalami perubahan dan pertambahan massa memiliki nilai rata-rata wadah adalah $0 \%$. Dari hasil pengujian porositas wadah terhadap air dapat diketahui bentuk wadah makanan piring kecil, piring besar dan mangkok kecil memiliki ketahanan sangat rendah dan tidak baik digunakan untuk meletakkan makanan yang berkuah dan kering.

Pada gambar 1 hasil pengujian dari uji porositas wadah makanan terhadap air untuk wadah tidak dianyam dalam berbagai bentuk sebagai berikut:

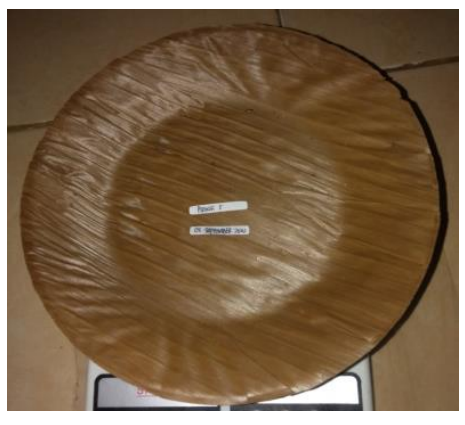

(a)

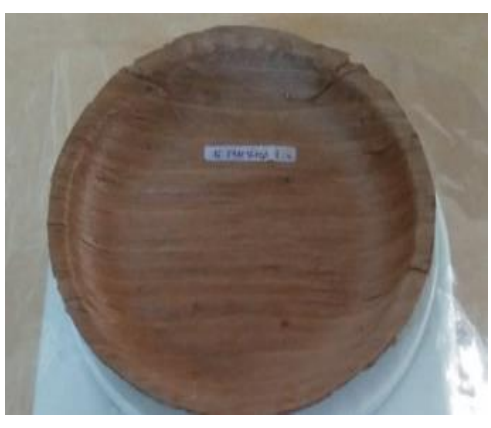

(b)

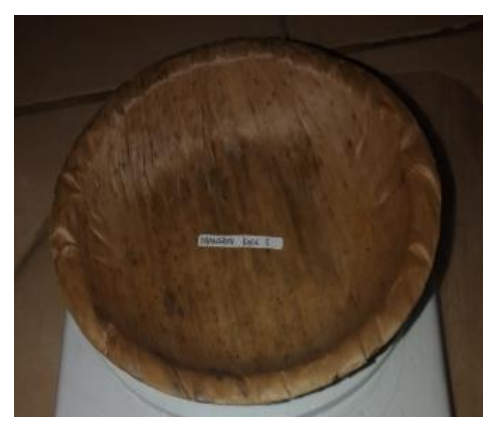

(c)

Gambar 1. Hasil Pengujian: Uji Porositas Wadah Makanan Terhadap Air Untuk Wadah tanpa Anyaman: (a) Piring Besar (b) Piring Kecil (c) Mangkok Kecil

Pada Tabel 2 terdapat nilai dari hasil uji porositas wadah makanan terhadap air untuk wadah makanan yang dianyam sebagai berikut: 
Tabe1 2. Uji Porositas Wadah Makanan Terhadap Air untuk Wadah Anyaman

\begin{tabular}{|c|c|c|c|c|c|}
\hline \multirow{2}{*}{ No } & \multirow{2}{*}{ Bentuk Wadah } & \multirow{3}{*}{$\begin{array}{c}\text { No } \\
\text { Wadah } \\
1\end{array}$} & \multicolumn{2}{|c|}{ Massa } & \multirow{2}{*}{$\begin{array}{c}\text { Hasil } \\
\text { DSA (\%) }\end{array}$} \\
\hline & & & Awal & Akhir & \\
\hline \multirow{3}{*}{1.} & \multirow{3}{*}{ Piring Kecil } & & 11.34 gram & 28.35 gram & 0,013 \\
\hline & & 2 & 14.17 gram & $25.51 \mathrm{gram}$ & 0,009 \\
\hline & & 3 & $11.34 \mathrm{gram}$ & 22.68 gram & 0,009 \\
\hline & \multirow[t]{2}{*}{ Rata- rata } & & $12.28 \mathrm{gram}$ & 25.51 gram & 0,106 \\
\hline & & 1 & 31.18 gram & 48.19 gram & 0,006 \\
\hline \multirow[t]{4}{*}{2.} & \multirow[t]{2}{*}{ Piring Besar } & 2 & 28.35 gram & 36.85 gram & 0,003 \\
\hline & & 3 & 28.35 gram & 42.52 gram & 0,005 \\
\hline & \multirow[t]{2}{*}{ Rata- rata } & & $29.29 \mathrm{gram}$ & 42.52 gram & 0,005 \\
\hline & & 1 & $17.01 \mathrm{gram}$ & 22.68 gram & 0,005 \\
\hline \multirow{3}{*}{3} & \multirow{2}{*}{ Mangkok Kecil } & 2 & $17.01 \mathrm{gram}$ & 28.35 gram & 0,005 \\
\hline & & 3 & 14.17 gram & 28.35 gram & 0,007 \\
\hline & Rata- rata & & 16.06 gram & 26.46 gram & 0,005 \\
\hline
\end{tabular}

Berdasarkan Tabel 2 diperoleh data Uji Porositas Wadah Makanan Terhadap air dengan berbagai jenis bentuk wadah makanan Seperti Piring besar, Mangkok Kecil dan Piring Kecil. Pertama wadah makanan dengan bentuk wadah makanan piring kecil diberikan perlakuan volume air sebesar 125 mill selama 60 menit mengalami pertambahan masa pada wadah memiliki nilai rata-rata adalah 0,106\%, Kedua wadah makanan dengan bentuk wadah makanan Piring besar diberikan perlakuan volume air sebesar $250 \mathrm{ml}$ selama 60 menit mengalami pertambahan massa memiliki nilai rata-rata prositas wadah adalah $0,005 \%$ dan Ketiga, wadah makanan dengan bentuk wadah makanan (mangkok kecil) yang diberi perlakuan yang berisi volume air sebesar $200 \mathrm{ml}$ selama 60 menit mengalami pertambahan massa dan memiliki nilai rata-rata adalah $0,005 \%$. Dari hasil pengujian porositas wadah dapat diketahui bentuk wadah makanan piring kecil, piring besar dan mangkok kecil memiliki porositas wadah yang tinggi dan tidak bagus digunakan untuk meletakkan makanan yang berkuah hanya cocok untuk makanan yang kering.

Pada gambar 2 hasil pengujian dari uji porositas wadah makanan terhadap air sebagai berikut:

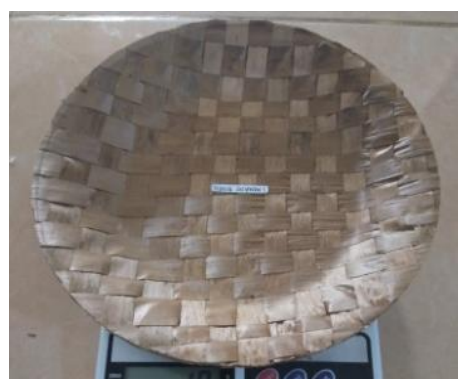

(a)

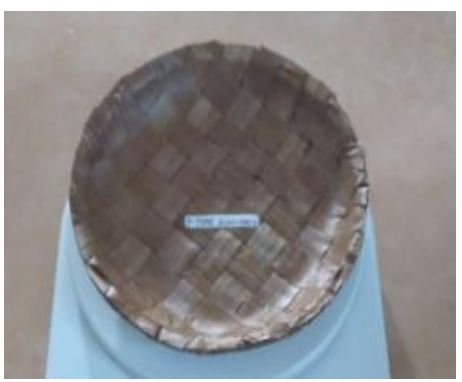

(b)

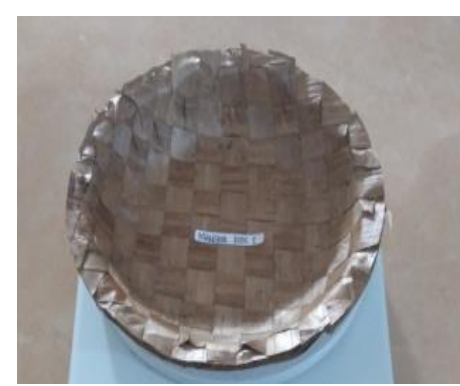

(c)

Gambar 2. Hasil Pengujian: Uji Porositas Wadah Makanan Terhadap Air:

(a) Piring Besar (b) Piring Kecil (c) Mangkok Kecil

\section{Uji Ketahanan Wadah Terhadap Suhu}

Pada Tabel 3 terdapat nilai dari hasil uji ketahanan wadah makanan terhadap suhu untuk wadah makanan yang tidak dianyam sebagai berikut: 
Tabel 3. Uji Ketahanan Wadah Terhadap Suhu untuk Wadah Tidak Dianyam

\begin{tabular}{ccccccc}
\hline No & $\begin{array}{c}\text { Bentuk } \\
\text { Wadah }\end{array}$ & $\begin{array}{c}\text { Suhu } \\
\left({ }^{\circ} \mathrm{C}\right)\end{array}$ & $\begin{array}{c}\text { Berubah } \\
\text { bentuk }\end{array}$ & $\begin{array}{c}\text { Terjadi } \\
\text { Rembesan }\end{array}$ & $\begin{array}{c}\text { Berubah } \\
\text { Warna }\end{array}$ & $\begin{array}{c}\text { Setelah di } \\
\text { keringkan }\end{array}$ \\
\hline \multirow{3}{*}{1} & Piring & 80 & - & - & - & - \\
& Kecil & 60 & - & - & - & - \\
& & 40 & - & - & - & - \\
2 & Piring & 80 & - & - & - & - \\
& Besar & 60 & - & - & - & - \\
\multirow{4}{*}{3} & Mangkok & 80 & - & - & - & - \\
& Kecil & 60 & - & - & - & - \\
\hline
\end{tabular}

Berdasarkan tabel 3, uji ketahanan wadah terhadap suhu dengan beberapa parameter yang diukur diperoleh hasil berbeda-beda yaitu pada suhu $80^{\circ} \mathrm{C}, 60{ }^{\circ} \mathrm{C}$ dan $40{ }^{\circ} \mathrm{C}$ untuk bentuk wadah Piring besar tidak terjadi rembesan, perubahan warna dan perubahan bentuk sebelum dikeringkan setelah wadah dikeringkan tidak terjadi perubahan bentuk sama sekali. Piring kecil untuk hasil parameter suhu $80^{\circ} \mathrm{C}, 60^{\circ} \mathrm{C}$ dan $40^{\circ} \mathrm{C}$ tidak terjadi rembesan, perubahan dan warna bentuk. Untuk wadah Mangkok diperoleh parameter suhu $80^{\circ} \mathrm{C}, 60^{\circ} \mathrm{C}$ dan $40^{\circ} \mathrm{C}$ tidak terjadi rembesan, perubahan warna dan perubahan bentuk sebelum dikeringkan setelah wadah dikeringkan tidak terjadi perubahan bentuk sama sekali. Hal ini menunjukkan bahwa bentuk wadah makanan dari piring kecil, piring besar dan mangkok kecil mampu mempertahankan keadaan wadah sampai pada suhu $80^{\circ} \mathrm{C}$.

Pada gambar 3 hasil pengujian dari uji ketahanan wadah makanan terhadap suhu $80^{\circ} \mathrm{C}$ untuk wadah tanpa dianyam dalam berbagai bentuk sebagai berikut:

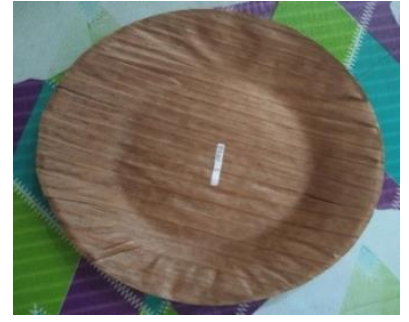

(a)

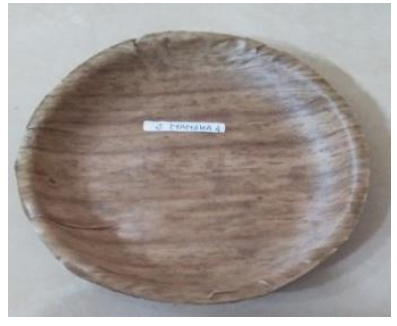

(b)

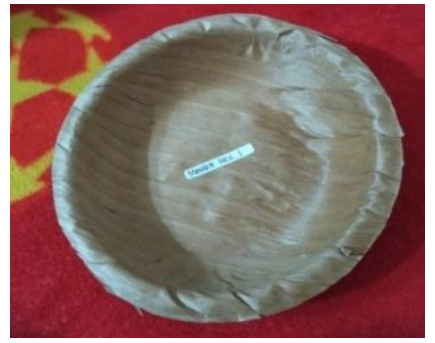

(c)

Gambar 3. Hasil Pengujian: Uji Ketahanan Wadah Makanan Terhadap Suhu $80^{\circ} \mathrm{C}$ Untuk Wadah tanpa dianyam: (a) Piring Besar (b) Piring Kecil (c) Mangkok Kecil

Pada gambar 4 hasil pengujian dari uji ketahanan wadah makanan terhadap suhu $60^{\circ} \mathrm{C}$ untuk wadah tanpa dianyam dalam berbagai bentuk sebagai berikut:

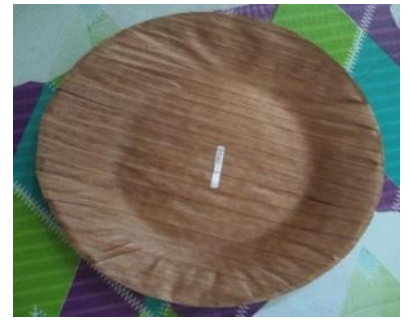

(a)

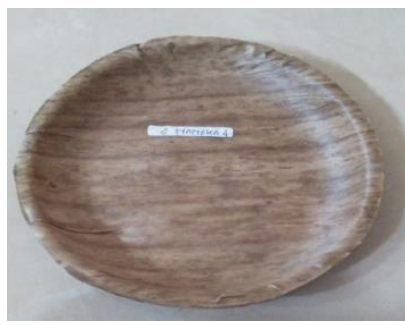

(b)

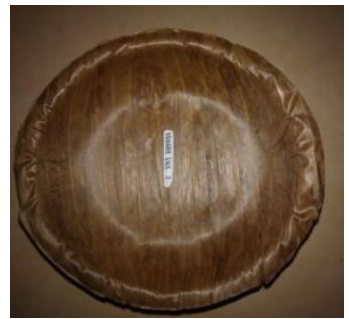

(c) 
Gambar 4. Hasil Pengujian: Uji Ketahanan Wadah Makanan Terhadap Suhu $60^{\circ} \mathrm{C}$ Untuk Wadah tanpa dianyam: (a) Piring Besar (b) Piring Kecil (c) Mangkok Kecil

Pada gambar 5 hasil pengujian dari uji ketahanan wadah makanan terhadap suhu $40^{\circ} \mathrm{C}$ untuk wadah tanpa dianyam dalam berbagai bentuk sebagai berikut:

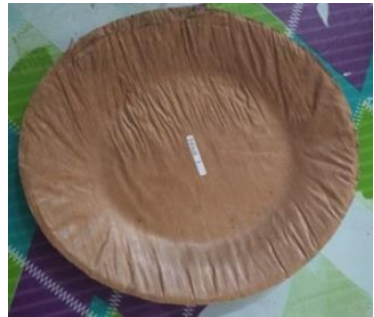

(a)

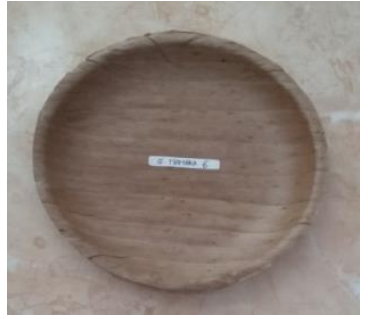

(b)

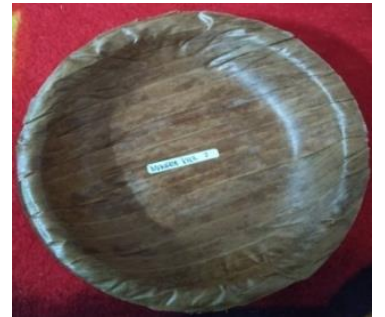

(c)

Gambar 5. Hasil Pengujian: Uji Ketahanan Wadah Makanan Terhadap Suhu $40^{\circ} \mathrm{C}$ Untuk Wadah tanpa dianyam: (a) Piring Besar (b) Piring Kecil (c) Mangkok Kecil

Tabel 4. Uji Ketahanan Wadah Terhadap Suhu untuk wadah anyaman

\begin{tabular}{ccccccc}
\hline \multirow{2}{*}{ No } & \multirow{2}{*}{ Bentuk Wadah } & $\begin{array}{c}\text { Suhu } \\
\left({ }^{\circ} \mathrm{C}\right)\end{array}$ & $\begin{array}{c}\text { Berubah } \\
\text { bentuk }\end{array}$ & $\begin{array}{c}\text { Terjadi } \\
\text { Rembesan }\end{array}$ & $\begin{array}{c}\text { Berubah } \\
\text { Warna }\end{array}$ & $\begin{array}{c}\text { Setelah di } \\
\text { keringkan }\end{array}$ \\
\hline \multirow{3}{*}{1} & \multirow{2}{*}{ Piring Kecil } & 80 & - & $\sqrt{ }$ & - & - \\
& & 60 & - & $\sqrt{ }$ & - & - \\
& & 40 & - & $\sqrt{ }$ & - & - \\
2 & \multirow{2}{*}{ Piring Besar } & 60 & - & $\sqrt{ }$ & - & - \\
& & 40 & - & $\sqrt{ }$ & - & - \\
& & 80 & - & $\sqrt{ }$ & - & - \\
& \multirow{2}{*}{ Mangkok Kecil } & 60 & - & $\sqrt{ }$ & - & - \\
& & 40 & - & $\sqrt{ }$ & - & - \\
\hline
\end{tabular}

Berdasarkan tabel 4, uji ketahanan wadah terhadap suhu dengan beberapa parameter yang diukur diperoleh hasil berbeda-beda yaitu pada suhu $80^{\circ} \mathrm{C}, 60^{\circ} \mathrm{C}$ dan $40^{\circ} \mathrm{C}$ untuk bentuk wadah Piring Kecil terjadi rembesan, perubahan warna dan perubahan bentuk sebelum dikeringkan setelah wadah dikeringkan tidak terjadi perubahan bentuk sama sekali. Piring Besar untuk hasil parameter suhu $80^{\circ} \mathrm{C}, 60^{\circ} \mathrm{C}$ dan $40^{\circ} \mathrm{C}$ terjadi rembesan, perubahan warna dan sebelum dikeringkan tidak terjadi perubahan bentuk setelah dikeringkan tidak terjadi perubahanan bentuk. Untuk wadah Mangkok Kecil diperoleh parameter suhu $80^{\circ} \mathrm{C}, 60^{\circ} \mathrm{C}$ dan $40^{\circ} \mathrm{C}$ terjadi rembesan, perubahan warna dan perubahan bentuk sebelum dikeringkan setelah wadah dikeringkan tidak terjadi perubahan bentuk sama sekali. Hal ini menunjukkan bahwa bentuk wadah makanan dari piring kecil, piring besar dan mangkok kecil mampu mempertahankan keadaan wadah sampai pada suhu $80^{\circ} \mathrm{C}$ tetapi rembesannya dia tidak bisa bertahan dalam 5 detik jadi wadah makanan anyaman ini hanya cocok untuk makanan kering saja.

Pada gambar 6 hasil pengujian dari uji ketahanan wadah makanan terhadap suhu $80^{\circ} \mathrm{C}$ untuk wadah dianyam dalam berbagai bentuk sebagai berikut: 


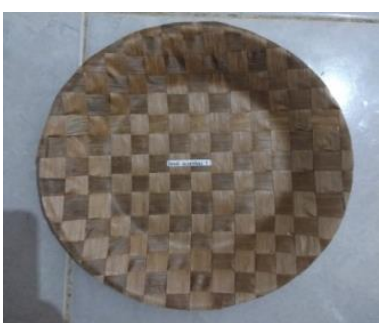

(a)

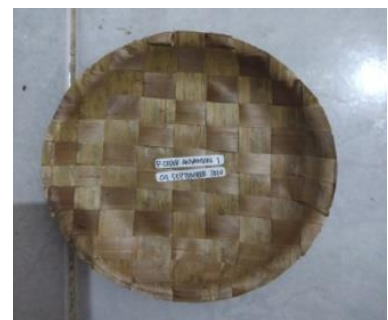

(b)

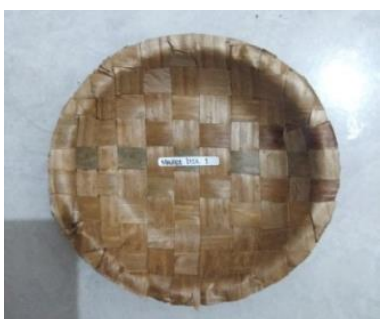

(c)

Gambar 6. Hasil Pengujian: Uji Ketahanan Wadah Makanan Terhadap Suhu $80^{\circ} \mathrm{C}$ Untuk Wadah dianyam: (a) Piring Besar (b) Piring Kecil (c) Mangkok Kecil

Pada gambar 7 hasil pengujian dari uji ketahanan wadah makanan terhadap suhu $60^{\circ} \mathrm{C}$ untuk wadah dianyam dalam berbagai bentuk sebagai berikut:

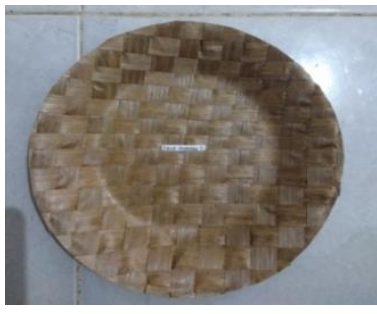

(a)

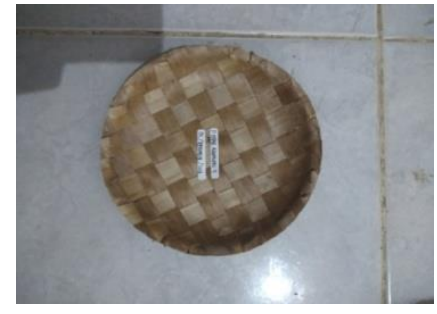

(b)

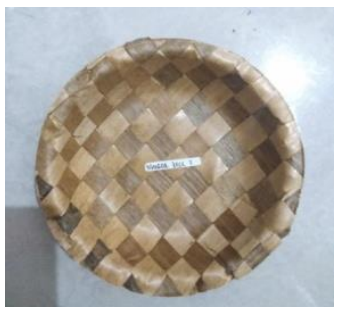

(c)

Gambar 7. Hasil Pengujian: Uji Ketahanan Wadah Makanan Terhadap Suhu $60^{\circ} \mathrm{C}$ Untuk Wadah dianyam: (a) Piring Besar (b) Piring Kecil (c) Mangkok Kecil

Pada gambar 8 hasil pengujian dari uji ketahanan wadah makanan terhadap suhu $40^{\circ} \mathrm{C}$ untuk wadah dianyam dalam berbagai bentuk sebagai berikut:

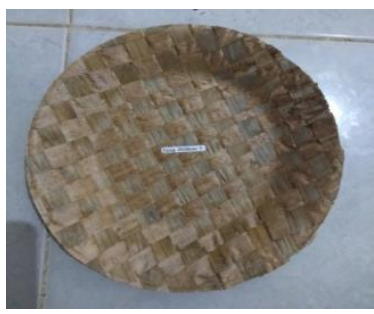

(a)

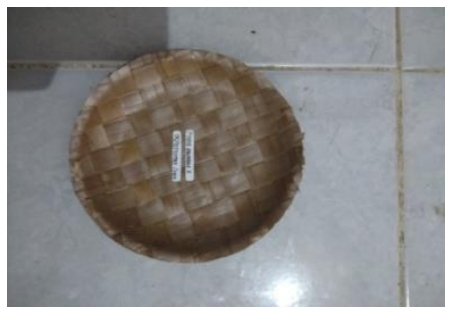

(b)

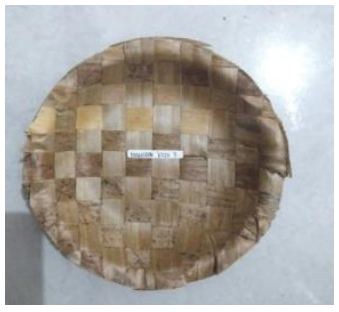

(c)

Gambar 8. Hasil Pengujian: Uji Ketahanan Wadah Makanan Terhadap Suhu $40^{\circ} \mathrm{C}$ Untuk Wadah dianyam: (a) Piring Besar (b) Piring Kecil (c) Mangkok Kecil

\section{KESIMPULAN}

Hasil Pengujian wadah makanan ada dua yaitu, Pertama Uji Porositas Wadah terhadap air dengan suhu $29,5^{\circ} \mathrm{C}$ dengan perlakuan volume air sebanyak $125 \mathrm{ml}$ ke piring kecil, $200 \mathrm{ml} \mathrm{ke}$ mangkok kecil dan $250 \mathrm{ml}$ ke piring besar selama 60 menit tidak mengalami pertambahan massa dengan nilai rata-rata wadah untuk wadah makanan tanpa anyaman untuk ketiga bentuk wadah makanan memiliki hasil yang sama yaitu $0,00 \%$, sedangkan anyaman mengalami pertambahan massa untuk wadah piring kecil sebesar 0,106\%, piring besar sebesar 0,005\% dan mangkok kecil sebesar $0,005 \%$. Pengujian kedua uji ketahanan wadah berdasarkan parameter suhu. Suhu yang digunakan 
yaitu suhu $40^{\circ} \mathrm{C}, 60^{\circ} \mathrm{C}$, dan $80^{\circ} \mathrm{C}$ untuk wadah makanan tanpa anyaman untuk ketiga bentuk wadah makanan memiliki hasil yang sama tidak terjadi perubahan sedangkan untuk wadah makanan anyaman untuk ketiga bentuk wadah makanan memiliki hasil yang sama yaitu terjadi rembesan (bocor) pada wadah.

Saran pada penelitian selanjutnya adalah sebaiknya menggunakan alat yang modern sehingga dapat menghasilkan lebih banyak bentuk jenis wadah yang beragam dan proses pengerjaanya lebih cepat.

\section{DAFTAR PUSTAKA}

[1] H. H. Arifki and M. I. Barliana, "Karakteristik Dan Manfaat Tumbuhan Pisang Di Indonesia : Review Artikel,” Bandung Univ. Padjadjaran, vol. 16, no. 30 Agustus, pp. 196-203, 2018.

[2] M. Nasrullah, N. Mukaromaini, A. M. Carolina, A. Asriwati, and E. S. Budiandini, "Pemanfaatan Daun Pisang Kering 'Klaras' Sebagai Bahan alternatif Tinta Isi Ulang Spidol Whiteboard yang Rendah VOC (Volatile Organic Compound)," Universitas Muhammadiyah Sidoarjo, 2015.

[3] Suparti and W. A. Safitri, "Media Alternatif Campuran Daun Pisang Kering dan Kulit Jaung untuk Meningkatkan Produktivitas Jamur Merang (Volvariella volcavea (Bull) Singer.) Dalam Keranjang.," Surakarta Univ. Mubammadiyah Surakarta, vol. 5, no. 1, pp. 69-73, 2020, doi: 10.23917/bioeksperimen.v6i1.2795.

[4] F. D. Izaak, F. A. Rauf, and R. Lumintang, "Analisis sifat mekanik dan daya serap air material komposit serat rotan," 2013.

[5] D. Santhi, Plastik sebagai kemasan makanan dan minuman, no. April. Universitas Udayana, 2016.

[6] L. Suryanegara, "Bahaya Kertas Cokelat Pembungkus," LIPI, 2018. .

[7] T. Kapasiang, M. Bukit, and J. Tarigan, "Penentuan Morfologi Permukaan dan Sifat Fisis serta Sifat Mekanik Batu Bata Asal Tanah Merah Kabupaten Kupang Nusa Tenggara Timur," Kupang Univ. Nusa Cendana, vol. 2, no. 2, 2017.

[8] N. Sucipta, K. Suriasih, and P. ketut D. Kencana, Pengemasan pangan (kajian pengemasan yang aman, nyaman, efektif dan efisien. Bali: universitas uduyana, 2017.

[9] L. A. Didik, "Pengukuran Kalor Jenis Material Menggunakan Modifikasi Persamaan Teorema Stefann Boltzman,” Konstan, vol. 2, no. 2, pp. 47-50, 2017.

[10] M. Irham Nurwidyanto, I. Noviyanti, and S. Widodo, "Estimasi Hubungan Porositas Dan Permeabilitas Pada Batupasir (Study Kasus Formasi Kerek, Ledok, Selorejo)," Berk. Fis., vol. 8, no. 3, pp. 87-90, 2005.

[11] Melone, L., L. Altomare, A. Cigada, and L. De Nardo, "Phase change material cellulosiccomposites for the cold storage of perishable 45products: from material preparation to computational evaluation," Appl. Energy, vol. 8, no. 1, pp. 339-346, 2012.

[12] M. Delgado, A. Lazaro, J. Mazo, and B. Zalba, "Review on phase change materialemulsions and microencapsulated phase changematerial slurries: materials, heat transfer studiesand applications," Sustain. Energy Rev., vol. 16, no. 1, pp. 253-273, 2012. 